\title{
The Xylitol Applicability and its Effects in Health Area Worldwide: A Bibliometric Analysis Based on Randomized Controlled Trials
}

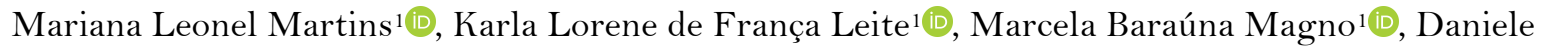

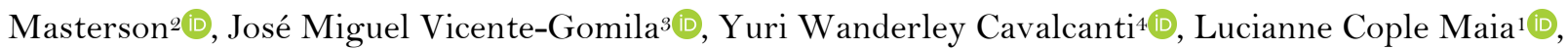 \\ Andréa Fonseca-Gonçalves ${ }^{1}$ (i)
}

${ }^{1}$ Department of Pediatric Dentistry and Orthodontics, School of Dentistry, Federal University of Rio de Janeiro, Rio de Janeiro, RJ,
Brazil.
${ }^{2}$ Central Library of the Health Science Center, Federal University of Rio de Janeiro, Rio de Janeiro, RJ, Brazil.
${ }^{3}$ Department of Engineering Projects, Universitat Politècnica de València, Pozuelo, Madrid, Spain.
${ }^{4}$ Department of Clinical and Social Dentistry, Federal University of Paraíba, João Pessoa, PB, Brazil.

Correspondence: Andréa Fonseca-Gonçalves, Rua Professor Rodolpho Paulo Rocco, 325, Cidade Universitária, Rio de Janeiro, RJ, Brazil.21941-971. E-mail: andrea.goncalves@odonto.ufrj.br

Academic Editor: Catarina Ribeiro Barros de Alencar

Received: 18 February 2021 / Review: 19 July 2021 / Accepted: 27 September 2021

How to cite: Martins ML, Leite KLF, Magno MB, Masterson D, Vicente-Gomila JM, Cavalcanti YW, et al. The xylitol applicability and its effects in health area worldwide: a bibliometric analysis based on randomized controlled trials. Pesqui Bras Odontopediatria Clín Integr. 2022; 22:e2 10046. https://doi.org/10.1590/pboci.2022.011

\begin{abstract}
Objective: To describe and evaluate the xylitol products' applicability and its effects in the health area worldwide utilizing a bibliometric analysis from randomized controlled trials (RCT) with humans. Material and Methods: Electronic searches were carried out in Medline/PubMed, Scopus, Cochrane Library, Web of Science, and VHL databases. The main data extracted were: year, area of applicability, type of treatment, country, journal, xylitol posology and concentration, presentation form, outcomes, and effects. Results: From 1476 studies, 257 were included. These studies were published between 1973-2021. The majority was carried out in dentistry (73.9\%) and under preventive treatment (67.4\%). These studies were developed in the USA (15.4\%) and published in Caries Research (6.6\%). The posology and concentration ranged between 0.004-67 g/day and 0.002-100\%, respectively. The xylitol is usually used in the chewing gum form (44.0\%), and for antimicrobial activity evaluation (38.5\%). A positive effect was observed in 204 studies (79.3\%) and was associated with xylitol concentration $\geq 15 \%$ ( $\mathrm{p}=0.007)$. Side effects were reported in $8.2 \%$ and were associated with posology $\geq 5 \mathrm{~g} /$ day ( $\mathrm{p}=0.03$ ). Conclusion: Most studies with xylitol were conducted to prevent diseases in the dentistry field. The chewing gum form and antimicrobial activity evaluation were more frequent. Most xylitol products have a positive effect, and few studies report side effects.
\end{abstract}

Keywords: Xylitol; Therapeutics; Randomized Controlled Trials as Topic; Bibliometrics. 


\section{Introduction}

Xylitol is a sugar alcohol (or polyol) found in fruits and vegetables and exhibits the same sucrose sweetness [1]. Its consumption has no physiological requirement and can be considered a sucrose substitute [2]. This product is found in various formulations, including chewing gum, tablet, candy, toothpaste, mouthwash, gel, and spray [3-5]. It can be used to prevent and / or treat diseases of different areas, such as dentistry, medicine, and nutrition [6-9].

In dentistry, the xylitol is used as an adjuvant method to dental caries prevention and is recommended as part of oral health promotion programs. It is a non-cariogenic sugar due to its inability to be metabolized by oral microorganisms [5]. The xylitol can also be used in medicine to treat, for example, acute otitis media (AOM) because of its antibacterial properties against Streptococcus pneumoniae [10,11] and to facilitate gastric emptying after surgical procedures [7,12]. In nutrition, solutions with xylitol can be used to control blood glucose levels [13,14], and malnutrition in postoperative patients $[15,16]$.

Due to its obtention and purification processes, the use of xylitol products is relatively expensive as a sweetener compared to sucrose. In addition, because it is poorly hydrolyzed and absorbed by the small intestine, it can cause osmotic diarrhea to flatulence when consumed in high amounts [10,13,17,18]. Simultaneously, there are controversies in the literature regarding the applicability, efficacy, and possible side effects arising from the use of xylitol in different health areas.

Therefore, the present study aimed to describe the published studies profile on this topic and evaluate the xylitol products' applicability and its effects in the health area worldwide through a bibliometric analysis based on randomized controlled trials with humans.

\section{Material and Methods}

\section{Eligibility Criteria}

Randomized controlled trials (RCT) in humans (P) treated with xylitol (I) compared to control treatment (negative or gold standard) or without receiving the intervention (C) to evaluate the effect on health (O) were included.

In vitro, ex vivo, and in situ studies, no randomized or no controlled studies in vivo, studies involving animals, case reports, literature reviews, observational studies, research protocols, and other studies that did not comply with the inclusion criteria were excluded.

\section{Literature Search Strategy}

Two examiners (MLM and MBM), guided by a librarian (DM), independently performed the search without restrictions on year nor language. The following electronic databases were searched: PubMed, Scopus, Cochrane Library, Web of Science, and VHL (Latin American and Caribbean Health Sciences Literature LILACS / Brazilian Dentristy Bibliography - BBO). MeSH terms, free terms, and Boolean operators (OR, AND) were used, organized according to the PICO search strategy (Table 1), and following each database's syntax rules. Alerts were created in the databases to indicate new searches, including articles published no later than August 2021

Reference management software (Online version of EndNote ${ }^{\mathrm{TM}}$, version $\mathrm{X} 7$, Thomson Reuters, Philadelphia, USA) was used to organize references and to read titles and abstracts. Then, examiners MLM and $\mathrm{AF}$ removed duplicates and performed the screening in the VantagePoint ${ }^{\mathrm{TM}}$ software (Search Technology, 
Inc., Florida, USA). Finally, articles in which the title and abstract did not contain sufficient information were analyzed in full by two independent examiners to verify their eligibility.

Table 1. Search strategy according to the different databases used in this study.

\begin{tabular}{|c|c|}
\hline Database & Strategy \\
\hline \multirow[t]{9}{*}{ PubMed } & \multirow{9}{*}{ 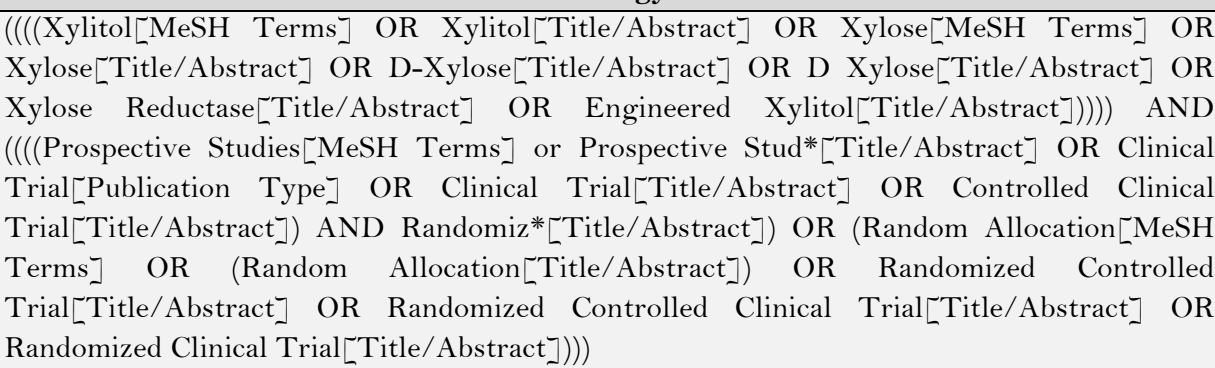 } \\
\hline & \\
\hline & \\
\hline & \\
\hline & \\
\hline & \\
\hline & \\
\hline & \\
\hline & \\
\hline Scopus & \multirow{7}{*}{$\begin{array}{l}\text { TITLE-ABS-KEY(Xylitol) OR TITLE-ABS-KEY(Xylose) OR TITLE-ABS-KEY(D-Xylose) } \\
\text { OR TITLE-ABS-KEY("D Xylose") OR TITLE-ABS-KEY("Xylose Reductase") OR TITLE- } \\
\text { ABS-KEY("Engineered Xylitol") AND ( ( TITLE-ABS-KEY ( prospective AND stud*) OR } \\
\text { TITLE-ABS-KEY ( "Clinical Trial" ) OR TITLE-ABS-KEY ( "Controlled Clinical Trial" )) } \\
\text { AND ( TITLE-ABS-KEY ( randomiz* ))) OR ( TITLE-ABS-KEY ( "Random Allocation" ) } \\
\text { OR TITLE-ABS-KEY ( "Randomized Controlled Trial" ) OR TITLE-ABS-KEY } \\
\text { "Randomized Controlled Clinical Trial" ) OR TITLE-ABS-KEY ( "Randomized Clinical } \\
\text { Trial" )) }\end{array}$} \\
\hline & \\
\hline & \\
\hline & \\
\hline & \\
\hline & \\
\hline & \\
\hline Web of Science & $\begin{array}{l}\text { (TS }=(\text { Xylitol OR Xylose OR D-Xylose OR "D Xylose" OR "Xylose Reductase" OR } \\
\text { "Engineered Xylitol") AND ((TS=(Prospective Stud* OR "Clinical Trial" OR "Controlled } \\
\text { Clinical Trial") AND TS=(Randomiz*) } \text { OR (TS=("Random Allocation" OR "Randomized } \\
\text { Controlled Trial" OR "Randomized Controlled Clinical Trial" OR "Randomized Clinical } \\
\text { Trial")))) }\end{array}$ \\
\hline \multirow[t]{25}{*}{ Cochrane Library } & Search Hits \\
\hline & MeSH descriptor: [Xylitol] explode all trees \\
\hline & xylitol 664 \\
\hline & MeSH descriptor: [Xylose $]$ explode all trees \\
\hline & xylose $\quad 130$ \\
\hline & D-xylose 67 \\
\hline & "D xylose" \\
\hline & "xylose reductase" o \\
\hline & "engineered xylitol" \\
\hline & \#1 OR \#2 OR \#3 OR \#4 OR \#5 OR \#6 OR \#7 OR \#8 793 \\
\hline & MeSH descriptor: [Prospective Studies $]$ explode all trees 94900 \\
\hline & prospective stud* 229350 \\
\hline & "clinical trial" \\
\hline & "controlled clinical trial" $\quad 266341$ \\
\hline & randomiz* \\
\hline & \#10 OR \#11 OR \#12 OR \#13 \\
\hline & \#15 AND \#14 643308 \\
\hline & MeSH descriptor: [Random Allocation] explode all trees 20643 \\
\hline & "random allocation" $\quad 26782$ \\
\hline & "randomized controlled trial" \\
\hline & "randomized controlled clinical trial" 12856 \\
\hline & "randomized clinical trial" 56742 \\
\hline & \#17 OR \#18 OR \#19 OR \#20 OR \#21 \\
\hline & \#16 OR \#22 \\
\hline & \#9 AND \#23 \\
\hline VHL (LILACS/BBO) & $\begin{array}{l}\text { ((mh:(xylitol)) OR (tw:(xylitol)) OR (mh:(xylose)) OR (tw:(xylose)) OR (tw:(D-xylose)) OR } \\
\text { (tw:(“D xylose”)) OR (tw:(“xylose reductase”)) OR (tw:(“engineered xylitol”))) AND } \\
\text { ((mh:(“random allocation”)) OR (tw:(“random allocation”)) OR (tw:(“randomized controlled } \\
\text { trial”)) OR (tw:(“randomized controlled clinical trial”)) OR (tw:(“randomized clinical trial”))) } \\
\text { OR (((mh:(“prospective studies”)) OR (tw:(prospective stud*)) OR (tw:(“clinical trial”)) OR } \\
\text { (tw:(“controlled clinical trial”))) AND (tw:(randomiz*))) }\end{array}$ \\
\hline
\end{tabular}




\section{Data Extraction}

Examiners MLM and KLFL performed complete reading and extraction of the data. A spreadsheet was created to standardize the data to be extracted, containing the following information: year (grouped into decades); age group of participants (infant - o to 1 year; child - 2 to 9 years; adolescent - 10 to 19 years; adult 20 to 60 years; elderly - up to 60 years); area of applicability, type of treatment (preventive, therapeutic, and indirect); country (in which the study was developed); journal; frequency and duration of the intervention and washout; xylitol posology and concentration; associated products; presentation form; outcomes; effect (positive, null or negative); and possible side effects. The indirect treatment was considered when it was applied to a mother, but the effect was investigated in her child.

In case of studies in which additional data were required or classified as a summary of the congress presentation, their authors were contacted by email to clarify doubts. Disagreements between the authors were settled by discussion, with a third author (AF) when necessary.

\section{Data Analyses}

Data analyses were carried out in the VantagePoint ${ }^{\mathrm{TM}}$ software (Search Technology, Inc., Florida, USA), Microsoft Office Excel 2010 ${ }^{\mathrm{TM}}$, and SPSS software version 21.0 (SPSS Inc., Chicago, USA). Descriptive and inferential data analyses were performed. For descriptive analyses, the same study could contain one or more classification options in the same variable (age group, area of applicability, type of treatment, xylitol concentration, associated products, presentation form, outcomes, effect, and possible side effects). This could become a total frequency value of these variables greater than the number of RCT included. For inferential data analyses, the Chi-square test was used to observe a possible association between the xylitol effect and data of the frequency of use $(<3 / \geq 3$ times/day), time of intervention $(<5 / \geq 5$ minutes per intervention; $<28 /$ $\geq 28$ days considering the total period of treatment), posology according to the presentation form $(<3 / \geq 3$ daily use of pieces; $<10 \mathrm{~mL} / \geq 10 \mathrm{~mL}$ or $<5 / \geq 5 \mathrm{~g} /$ day), xylitol concentration $(<15 / \geq 15 \%)$, other active compounds in the same product containing xylitol (yes or no) and other interventions (yes or no). The level of significance considered was $5 \%(\mathrm{p}<0.05)$

\section{Results}

Initially, the authors identified 1476 studies. After removing duplicates, 890 studies remained. Of these, 593 were excluded after reading the titles and abstracts, and 297 were selected for reading the full text carefully. After this step, 40 studies were excluded because they did not meet the eligibility criteria, and 257 were selected and progressed to the quantitative synthesis and data extraction stages (Figure 1).

\section{Year of Publication and Age Groups}

The RCT included in this bibliometric study were published between 1973 and 2021. The production was higher between 2011-2021 $(n=119 ; 46.3 \%)$, and 2001-2010 $(n=67 ; 26.1 \%)$, follow by 1991-2000 $(n=45$; $17.5 \%), \quad 1981-1990(\mathrm{n}=15 ; 5.8 \%)$, and $1973-1980(\mathrm{n}=11 ; 4.3 \%)$. Distribution of age groups, areas of applicability, and types of treatment over the years are represented in Figures 2, 3, and 4 .

Most studies were conducted with adults $(n=162 ; 63.0 \%)$, and a minor number were carried out with infants $(n=7 ; 2.7 \%)$. One study did not report the age group and was not included in this analysis. On the other hand, some authors included different age groups (Figure 2). 


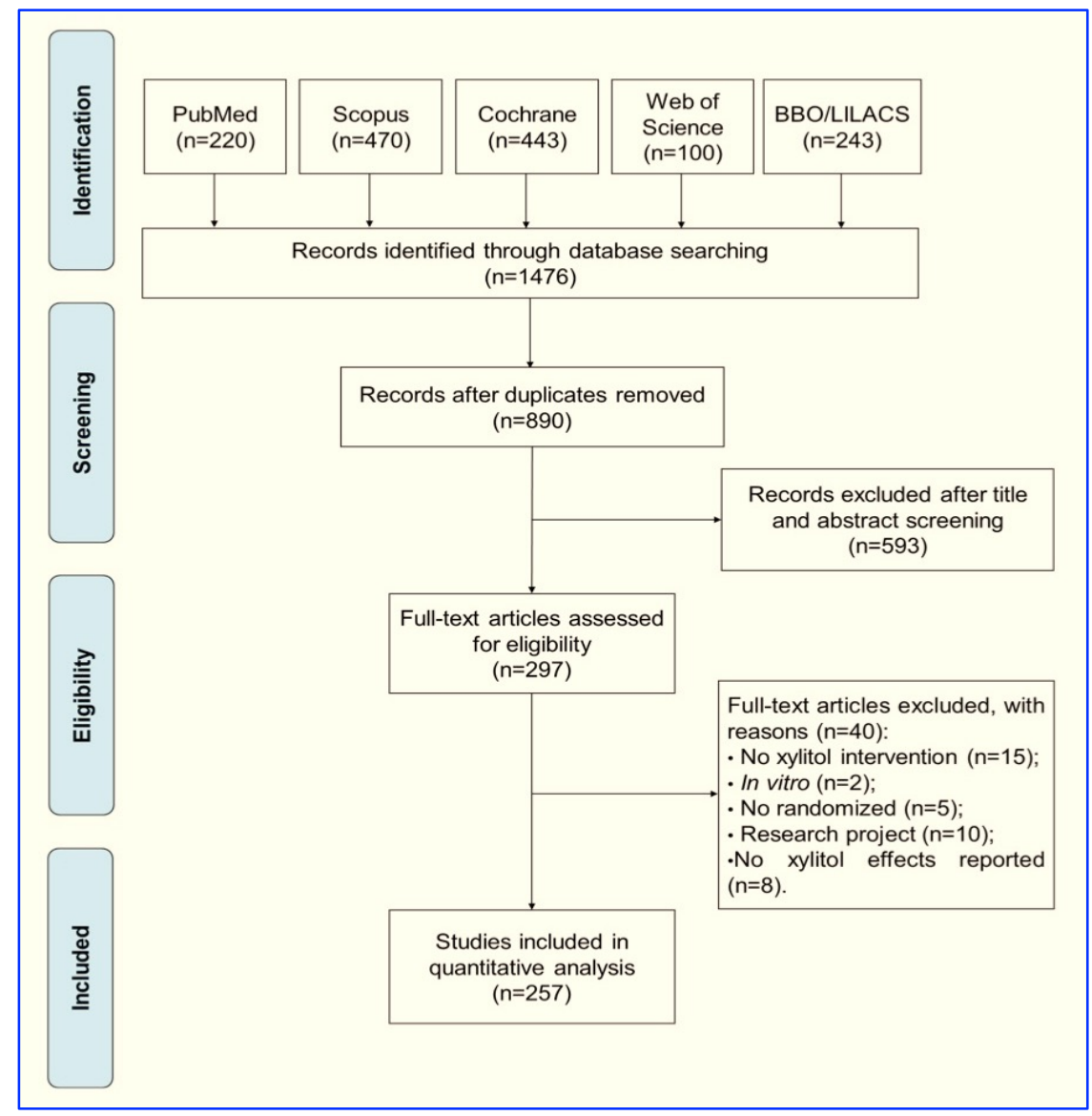

Figure 1. Flowchart of search results in databases.

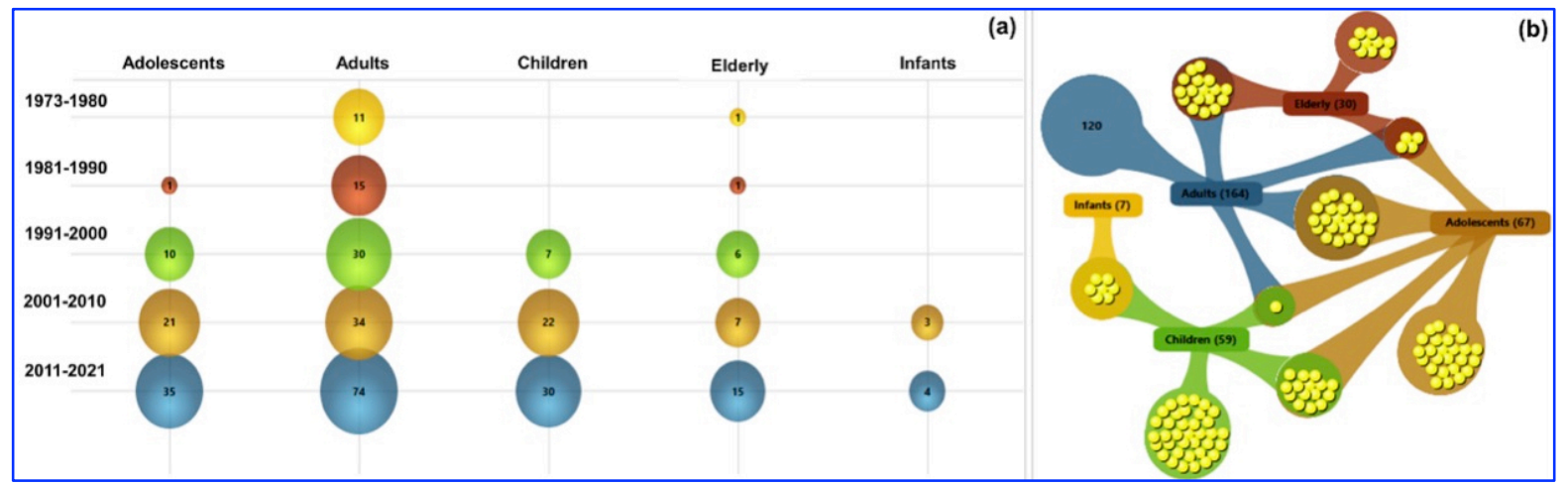

Figure 2. Bubble chart of the studies distribution over the years by age group (a) and cluster map of the age groups (the intersection among them indicates the number of studies with different age groups simultaneously) (b). There is no correspondence between the colors in figures $2 \mathrm{a}$ and $2 \mathrm{~b}$.

Area of Applicability, Type of Treatment, Countries, and Journals of Publication

The more frequent health area was dentistry $(n=190 ; 73.9 \%)$, followed by medicine $(n=38 ; 14.8 \%)$. Some studies were included in different areas simultaneously (Figure 3).

The preventive treatment management $(\mathrm{n}=160 ; 62.3 \%)$ was the most frequent and also was evaluated simultaneously with therapeutic treatment in 13 studies (5.1\%) (Figure 4). The type of intervention was classified as main $(\mathrm{n}=250 ; 97.3 \%)$ or complementary $(\mathrm{n}=7 ; 2.7 \%)$. Other interventions, such as dental restorative treatments performed simultaneously with xylitol-containing products, were carried out in 36 studies $(14.0 \%)$. 


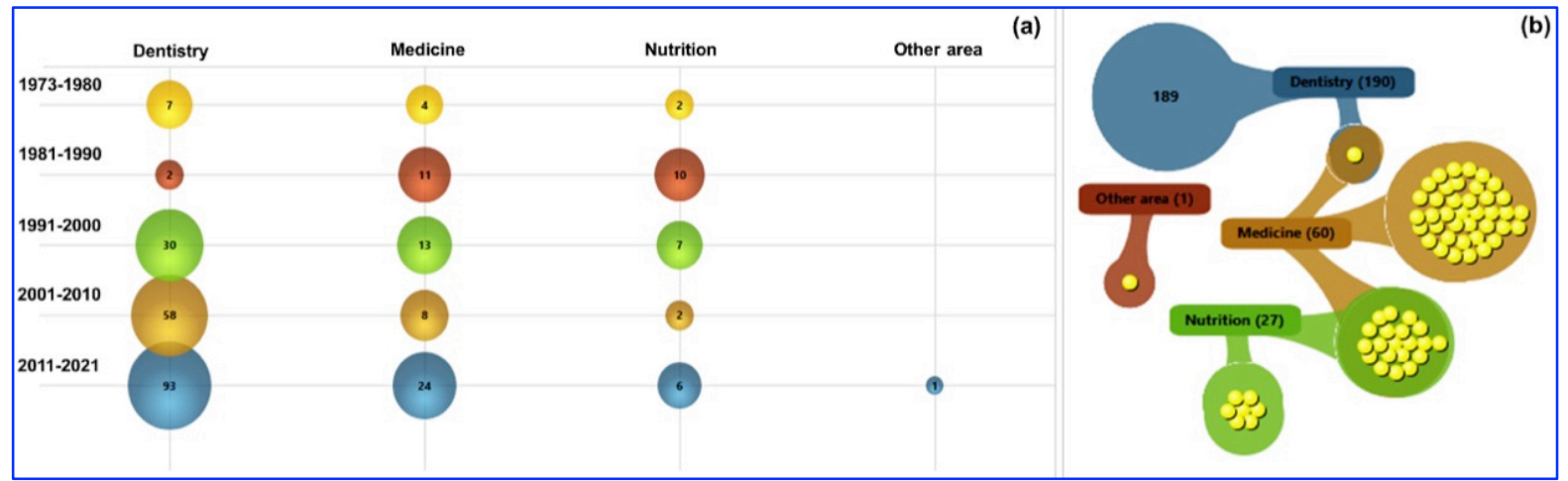

Figure 3. Bubble chart of the studies distribution over the years by area (a) and cluster map of the areas of applicability (the intersection among them indicates the number of studies about different areas simultaneously) (b). There is no correspondence between the colors in figures $3 \mathrm{a}$ and $3 \mathrm{~b}$.

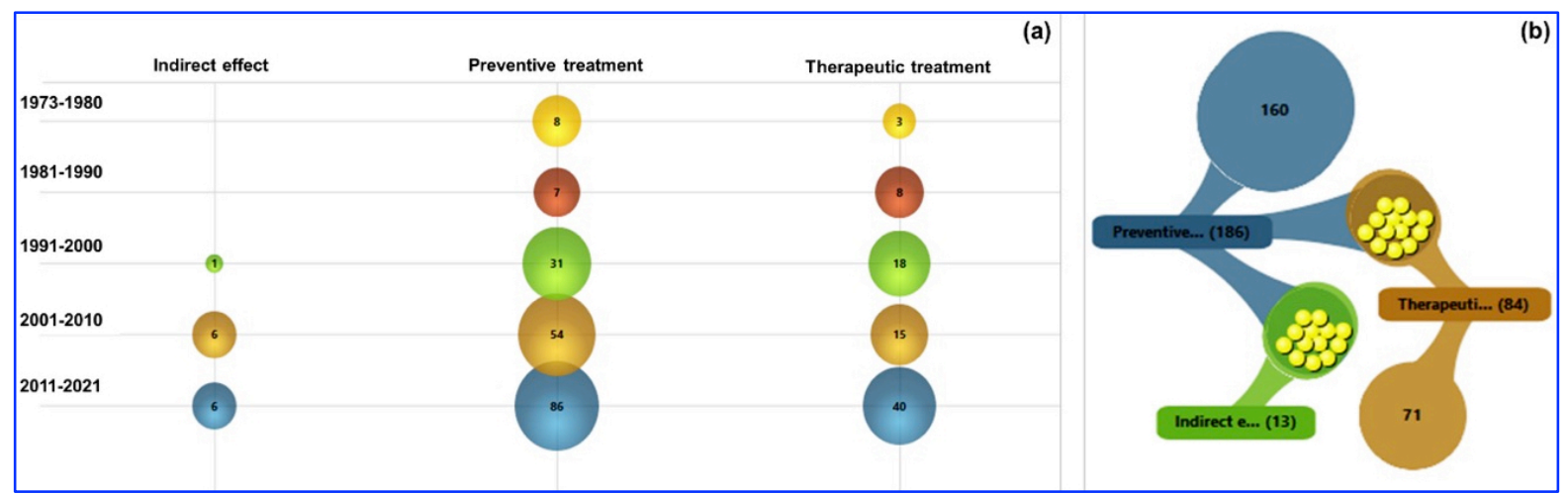

Figure 4. Bubble chart of the studies distribution over the years by treatment (a) and cluster map of the types of treatment (the intersection among them indicates the number of studies with different types of treatment simultaneously) (b). There is no correspondence between the colors in figures $4 \mathrm{a}$ and $4 \mathrm{~b}$.

The papers originated from 39 countries and were published in 143 journals, with a more significant number of studies from the United States of America (USA) (n=39; 15.4\%) (Figure 5).

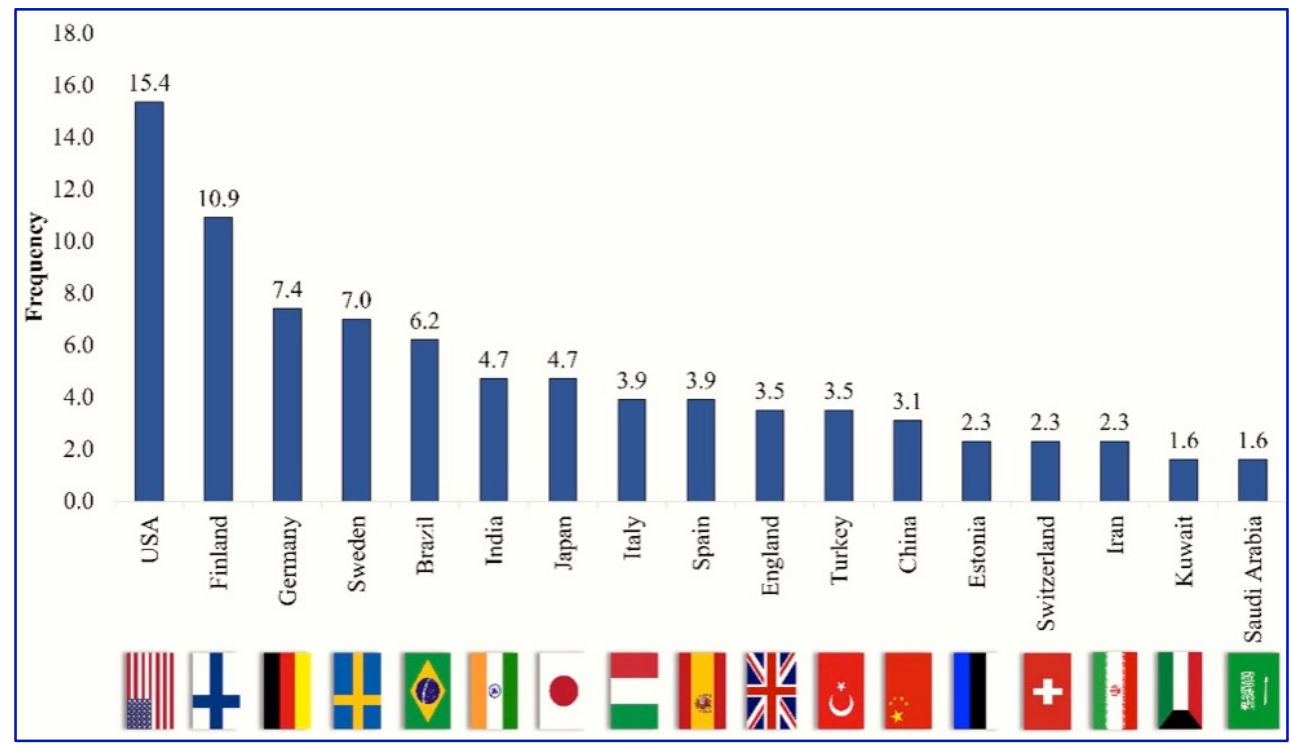

Figure 5. Frequency of countries with five or more randomized clinical trials in humans with xylitol worldwide. 
Among journals with four or more publications, 12 were from the dentistry area, and one was from the nutrition area. The journal with the highest number of published RCT about xylitol was Caries Research $(\mathrm{n}=17 ; 6.6 \%)$, and the Journal of Clinical Periodontology presented the highest impact factor $(\mathrm{IF}=5.24)($ Table $2)$.

Table 2. Frequency of journals with four or more randomized clinical trials published about xylitol over the years.

\begin{tabular}{lccccccc}
\hline \multicolumn{1}{c}{ Journal } & & \multicolumn{3}{c}{ Years } & & Total & IF* \\
& 1973-1980 & 1981-1990 & 1991-2000 & 2001-2010 201 1-2021 & & \\
\hline Caries Research & 0 & 1 & 4 & 5 & 7 & 17 & 2.18 \\
Acta Odontologica Scandinavica & 4 & 0 & 3 & 3 & 1 & 11 & 1.57 \\
Clinical Oral Investigations & - & - & 0 & 2 & 7 & 9 & 2.81 \\
Journal of Dental Research & 0 & 0 & 3 & 2 & 2 & 7 & 4.91 \\
Oral Health and Preventive Dentistry & 0 & 0 & 0 & 3 & 4 & 7 & 0.92 \\
Infusionstherapie und Klinische Ernährung & 1 & 5 & 0 & 0 & 0 & 6 & - \\
Journal of Clinical Periodontology & 1 & 0 & 2 & 3 & 0 & 6 & 5.24 \\
Community Dentistry and Oral Epidemiology & 0 & 0 & 1 & 1 & 2 & 4 & 2.13 \\
European Journal of Oral Sciences & 0 & 0 & 2 & 2 & 0 & 4 & 2.22 \\
Indian Journal of Dental Research & 0 & 0 & 0 & 0 & 4 & 4 & 0.37 \\
International Journal of Paediatric Dentistry & - & - & 0 & 2 & 2 & 4 & 1.99 \\
Journal of Clinical Pediatric Dentistry & - & - & 0 & 0 & 4 & 4 & 0.94 \\
Journal of Dentistry for Children & - & - & - & 1 & 3 & 4 & 0.66 \\
\hline
\end{tabular}

*IF: Impact Factor. (-) Clinical Oral Investigations, International Journal of Paediatric Dentistry, Journal of Clinical Pediatric Dentistry, and Journal of Dentistry for Children started their publications in 1997, 1991, 1990, and 2002, respectively. The Infusionstherapie und Klinische Ernährung was discontinued and has no IF.

\section{Xylitol Concentration, Frequencies of Dosage and Washout Period}

In studies that presented more than one xylitol concentration tested, the mean value was considered. Among the studies that reported the xylitol posology, 78 (58.6\%) used products with a dosage $<5 \mathrm{~g} /$ day and $55(41.4 \%)$ used it $\geq 5 \mathrm{~g} /$ day, while among the studies that reported the xylitol concentration, $23(41.1 \%)$ used a xylitol concentration $<15 \%$ and $33(58.9 \%)$ tested it $\geq 15 \%$. The highest frequencies of dosage were 2 pieces/day $(\mathrm{n}=17 ; 6.6 \%), 6$ pieces/day $(\mathrm{n}=15 ; 5.8 \%)$, and $10 \mathrm{~mL} /$ intervention $(\mathrm{n}=11 ; 4.3 \%)$. Most crossover studies considered a washout period of $7(n=16 ; 40.0 \%)$ or 14 days $(n=6 ; 15.0 \%)$ (Table 3$)$.

Table 3. Characteristics of the RCT included in the bibliometric analysis.

\begin{tabular}{lccc}
\multicolumn{1}{c}{ Variables } & $\begin{array}{c}\text { Studies } \\
\mathrm{N}(\%)\end{array}$ & Mean (SD) & Range \\
\hline $\begin{array}{l}\text { Frequency (Daily) } \\
\text { Intervention Time }\end{array}$ & $170(66.1)$ & $3.3(1.8)$ & $1-15$ \\
$\quad \begin{array}{l}\text { Minutes } \\
\text { Days }\end{array}$ & $91(35.4)$ & $8.7(8.1)$ & $0.25-35$ \\
Xylitol Concentration & $239(93.0)$ & $173.4(312.9)$ & $1-1461$ \\
$\quad \%$ & & & \\
Dosage & $56(21.8)$ & $32.0(33.0)$ & $0.002-100$ \\
$\quad$ Gram/Day & $133(51.8)$ & $6.4(10.6)$ & $0.004-67$ \\
$\quad$ Pieces/Day & $61(23.7)$ & $4.6(3.2)$ & $1-14$ \\
$\quad$ mL/Intervention & $20(7.8)$ & $36.0(69.3)$ & $0.25-300$ \\
Washout (Days) & $40(15.6)$ & $11.9(14.5)$ & $0.007-84$ \\
\hline
\end{tabular}

Presentation Form and Other Active Compounds

Some studies included in this bibliometric analysis tested more than one xylitol presentation form, associated products, and/or outcomes. The products exhibited a several presentation form, among them the 
more common are chewing gum (44.0\%), tablet (10.9\%), parenteral nutrition solution (10.5\%), mouthwash $(9.3 \%)$, and toothpaste $(7.0 \%)$ (Table 4$)$.

Products containing xylitol as a single active compound were reported in 160 studies (62.3\%) and they were associated with other active compounds in 90 studies (35.0\%). Seven studies did not report the compounds (2.7\%). The main associations were with sorbitol (10.1\%), fluoride (8.5\%), glucose (3.5\%), and chlorhexidine (2.3\%), respectively (Table 4$)$.

Outcomes and Effects

The main outcomes evaluated were antimicrobial activity (39.3\%), dental biofilm (plaque and calculus) (26.1\%), dental caries (DMF-T, ICDAS, white spots lesions) (19.8\%), salivary parameters (salivary flow, pH and buffer capacity) (13.2\%), periodontal condition (10.9\%), blood glucose levels (9.7\%), xerostomia (5.0\%), gastric emptying (3.1\%), nasal symptoms (nasal obstruction, sneezing, rhinorrhea, snoring, headache, facial pain, and olfactory changes) (3.1\%), quality of life (QoL) (3.1\%), and acute otitis media (AOM) (2.7\%) (Table 4).

A positive effect was observed in 204 studies, a null effect in 63 studies, and a negative effect in 27 studies (10.5\%). Among the outcomes in which xylitol had a negative effect, dental caries was the most frequent $(25.9 \%)$. A statistically significant difference regarding the xylitol products' effect was observed only for the xylitol concentration variable, since $90.0 \%$ of the products that presented xylitol concentration $\geq 15 \%$ exhibited a positive effect for the evaluated outcome $(\mathrm{p}=0.007)$ (Table 5).

Possible side effects associated with the use of xylitol products were reported in 21 (8.2\%) studies, which were gastrointestinal effect as bloating, flatulence, bowel sounds, nauseas, vomiting, and diarrhea $(n=14$; $5.4 \%)$, oral burning $(\mathrm{n}=2 ; 0.8 \%)$, and atopic eczema $(\mathrm{n}=2 ; 0.8 \%)$. Eighty-three studies $(32.3 \%)$ did not find any adverse effect, and the majority of the studies did not mention about side effects $(n=153 ; 59.5 \%)$. Products in solution $(n=3 ; 75 \%)$ and tablet forms $(n=5 ; 45.5 \%)$ demonstrated a higher frequency of possible side effects. Among these, the gastrointestinal side effects were associated with a xylitol concentration $\geq 5 \mathrm{~g} /$ day $(\mathrm{n}=10$; $83.3 \%)(\mathrm{p}=0.03)$.

Table 4. Frequency of the presentation form, association with active compounds, and main outcomes of the RCT with xylitol intervention.

\begin{tabular}{lcc}
\hline \multicolumn{1}{c}{ Variables } & $\mathbf{N}$ & \% \\
\hline Presentation Form & & 40.9 \\
Chewing Gum & 113 & 10.1 \\
Tablet & 28 & 9.8 \\
Parenteral Nutrition Solution & 27 & 8.7 \\
Mouthwash & 24 & 6.5 \\
Toothpaste & 18 & 6.2 \\
Oral Solution & 17 & 3.3 \\
Nasal Irrigation Solution & 9 & 2.9 \\
Candy & 8 & 2.2 \\
Spray & 6 & 1.8 \\
Wipe & 6 & 1.8 \\
Varnish & 5 & 1.4 \\
Gel & 5 & 1.1 \\
Sweetener & 4 & 1.1 \\
Syrup & 3 & 0.7 \\
Powder & 3 & 1.5 \\
Others & 276 & 100.0 \\
Total & 4 &
\end{tabular}




\begin{tabular}{|c|c|c|}
\hline \multicolumn{3}{|l|}{ Associated Products } \\
\hline Isolated Xylitol & 158 & 61.5 \\
\hline Sorbitol & 26 & 10.1 \\
\hline Fluoride & 22 & 8.5 \\
\hline Glucose & 9 & 3.5 \\
\hline Chlorhexidine & 6 & 2.4 \\
\hline Fructose & 4 & 1.6 \\
\hline Malic Acid & 4 & 1.6 \\
\hline Probiotic & 3 & 1.1 \\
\hline Bicarbonate & 3 & 1.1 \\
\hline Green Tea & 2 & 0.8 \\
\hline Funoran Extract & 2 & 0.8 \\
\hline Magnolia & 2 & 0.8 \\
\hline Others & 9 & 3.5 \\
\hline Not Informed & 7 & 2.7 \\
\hline Total & 257 & 100.0 \\
\hline \multicolumn{3}{|l|}{ Main Outcomes } \\
\hline Antimicrobial Activity & 101 & 26.5 \\
\hline Dental Biofilm & 68 & 17.9 \\
\hline Dental Caries & 51 & 13.4 \\
\hline Salivary Parameters & 34 & 8.9 \\
\hline Periodontal Condition & 28 & 7.4 \\
\hline Blood Glucose Levels & 25 & 6.6 \\
\hline Xerostomia & 12 & 3.1 \\
\hline Gastric Emptying & 9 & 2.4 \\
\hline Nasal Symptoms & 8 & 2.1 \\
\hline Quality of Life & 8 & 2.1 \\
\hline Acute Otitis Media & 7 & 1.8 \\
\hline Malnutrition & 6 & 1.6 \\
\hline Halitosis & 4 & 1.0 \\
\hline Respiratory Tract Infections & 4 & 1.0 \\
\hline Salivary/Biofilm Xylitol Concentrations & 3 & 0.8 \\
\hline Others & 13 & 3.4 \\
\hline Total & 381 & 100.0 \\
\hline
\end{tabular}

Table 5. Association between the xylitol products effect and data of frequency, time of intervention, dosage, concentration, composition, and other interventions in the RCT included in the bibliometric analysis.

\begin{tabular}{|c|c|c|c|}
\hline \multirow[b]{2}{*}{ Variables } & \multicolumn{2}{|c|}{ Xylitol Products Effect } & \multirow[b]{2}{*}{ p-value* } \\
\hline & $\begin{array}{l}\text { Positive } \\
\text { N (\%) }\end{array}$ & $\begin{array}{c}\text { Null / Negative } \\
\text { N (\%) }\end{array}$ & \\
\hline \multicolumn{4}{|l|}{ Frequency of Xylitol Use (Daily) } \\
\hline$<3$ times & $38(66.7)$ & $19(33.3)$ & 0.630 \\
\hline$\geq 3$ times & $140(70.0)$ & $60(30.0)$ & \\
\hline \multicolumn{4}{|l|}{ Time of Intervention (min) } \\
\hline$<5 \min$ & $16(69.6)$ & $7(30.4)$ & 0.923 \\
\hline$\geq 5 \min$ & $155(68.6)$ & $71(31.4)$ & \\
\hline \multicolumn{4}{|c|}{ Time of Intervention (Total Period of Treatment) } \\
\hline$<28$ days & $78(70.9)$ & $32(29.1)$ & 0.620 \\
\hline$\geq 28$ days & $100(68.0)$ & $47(32.0)$ & \\
\hline \multicolumn{4}{|l|}{ Number of Pieces (daily) } \\
\hline$<3$ pieces & $20(83.3)$ & $4(16.7)$ & 0.106 \\
\hline$\geq 3$ pieces & $150(67.3)$ & $73(32.7)$ & \\
\hline \multicolumn{4}{|l|}{ Dosage $(\mathrm{mL})$} \\
\hline$<10 \mathrm{~mL}$ & $3(100.0)$ & $\mathrm{o}(0.0)$ & 0.241 \\
\hline
\end{tabular}




\begin{tabular}{|c|c|c|c|}
\hline$\geq 10 \mathrm{~mL}$ & $167(68.4)$ & $77(31.6)$ & \\
\hline \multicolumn{4}{|c|}{ Dosage (gram/day) } \\
\hline$<5 \mathrm{~g} /$ day & $46(59.0)$ & $32(41.0)$ & 0.063 \\
\hline$\geq 5 \mathrm{~g} /$ day & $41(74.5)$ & $14(25.5)$ & \\
\hline \multicolumn{4}{|l|}{ Xylitol (\%) } \\
\hline$<15 \%$ & $11(47.8)$ & $12(52.2)$ & 0.007 \\
\hline$\geq 15 \%$ & $27(81.8)$ & $6(18.2)$ & \\
\hline \multicolumn{4}{|c|}{ Other Active Compounds } \\
\hline Yes & $63(70.0)$ & $27(30.0)$ & 0.759 \\
\hline No & $109(68.1)$ & $51(31.9)$ & \\
\hline \multicolumn{4}{|c|}{ Other Interventions } \\
\hline Yes & $25(69.4)$ & $11(30.6)$ & 0.979 \\
\hline No & $153(69.2)$ & $68(30.8)$ & \\
\hline
\end{tabular}

*Statistical analyses were performed using the Chi-Square test, and the significance level was considered as $\mathrm{p}<0.05$.

\section{Discussion}

Bibliometrics is a method used to draw the panoramic view and the current state of research on a given subject. This method consists of descriptive and quantitative analyses that aim to identify the characteristics of publications in a specific field of study, providing information for developing health research strategies [19]. Thus, in this study, the profile of clinical trials with xylitol and its applicability were described to inform healthcare professionals about the possible benefits of using products containing xylitol in different clinical conditions and assisting in the development of future research on the topic.

In the present bibliometric analysis, the studies selected were limited to RCT, which are characterized as the most relevant primary studies when considering the production of scientific evidence in the face of interventions [20]. So, two hundred fifty-seven RCT were included, and their data were extracted to evaluate the xylitol applicability and its effects worldwide.

Over the years, there has been an increase in the number of RCT with xylitol, which may suggest a large search and use for alternative products instead of conventional therapies for different clinical outcomes. This increase was greater in dentistry, which also grouped most studies. This can be justified due to the large number of clinical outcomes related to dentistry and, consequently, their greater applicability in this area.

In order to standardize the classification of the age groups between different studies, the World Health Organization criteria were considered [21]. Adults were more common in the present study, probably because the included studies with elderly (70\%) and adolescents (31.3\%) also incorporated adults in their sample, and by the facility in carrying out studies with this population compared to children.

Preventive treatment prevailed among studies and was performed to evaluate especially antimicrobial action [22-30], dental biofilm control [23,25,28,31] and blood glucose levels [9,13,14,32], while the therapeutic treatment was tested mainly for xerostomia [33-36], halitosis [35,37-39], gastric emptying $[7,8,40,41]$, and respiratory tract infections [11,42]. The studies cited above showed a positive effect, which suggests that xylitol can be used for such outcomes if it follows the other characteristics of the studies' interventions.

The indirect treatment was observed in only 13 studies, all about dentistry [43-55]. In these studies, the mother-child transmission and the effect of products containing xylitol against dental caries, periodontal conditions, and /or counts of oral microorganisms in mother and child were assessed. Although some of these studies have shown a positive effect, this may be associated with non-evaluated confounding factors, such as the bias in the measurement of outcomes due to the lack of blinding and calibration of the examiners. It is known 
that this type of indirect effect is no longer considered due to the change in paradigms related to the etiology of dental caries $[56,57]$.

Industrialized products containing xylitol have been used in several countries, especially by the food and pharmaceutical industries [58]. The significant number of countries included in this research reflects the global use of xylitol. The USA contributed most to the overall production of xylitol studies, followed by Finland and Germany. The high number of studies in these countries may be due to the greater consumption and addition to the population's diet. Brazil appeared among the top 10 countries with the largest production of studies on the subject, despite the fact that the Brazilian population did not frequently consume xylitol products due to their high cost. This finding can be justified because it is one of the countries with the most publications in dentistry [59].

The Caries Research was the journal with the largest number of publications, which can be justified by the most significant number of dentistry studies and due to the scope of the journal, as well as the relationship between xylitol and this topic. Although the studies have not been evaluated for their methodological quality, it is assumed that, as Caries Research is one of the leading journals with an excellent impact factor in the area, the investigated dentistry studies probably have a good methodological rigor [60]. Besides, the journal with the highest impact factor was the Journal of Clinical Periodontology, also of dentistry area.

The frequency and duration of the intervention and the washout period in crossover studies vary according to the type of treatment, outcome assessed, and also due to the different objectives and protocols among the studies evaluated. The greater frequency daily (10 and $15 \times$ ) was observed for preventive treatment $[61,62]$. Dental caries was the outcome that presented a longer time of intervention (4-year) probably because some clinical changes in this outcome can be better observed in the long term [47], while some interventions that evaluated blood glucose levels, salivary parameters, halitosis, and urinary effects, for example, were performed only once [14,63-67], considering that variations in these outcomes may occur in the short term. The washout was longer to gastric emptying (12-week) [68], while the short term (1 day) was regarding salivary parameters [69] and halitosis [64]. It is expected that the longer the frequency and duration of interventions, the results would be more favorable [70]. However, it becomes more difficult the treatment adherence and follow-ups of participants, besides the possibility of unforeseen confounding factors in long-term studies.

The lowest daily xylitol posology (0.004 $\mathrm{g} /$ day) was used for two weeks as a therapeutic treatment to nasal symptoms, in the form of a nasal irrigation solution (0.002\%) [71], and as an indirect treatment to reduce the colony count of Streptococcus mutans, in saliva and biofilm, for 9 months, in chewing gum form [48]. The highest daily xylitol posology (67 g/day) was also tested for 2 years as an indirect treatment against the colony count of $S$. mutans in saliva and dental caries in chewing gum form [43]. The highest xylitol concentration $(100 \%)$ was tested as a preventive treatment in adolescents to control the colony count of $S$. mutans in saliva for $1 \mathrm{month}$, also in chewing gum form (2.56 g/day) [22]. Despite the variability of the studies, an overview about the potential of chewing gums in oral health suggested that a dosage of 5-10 g/day xylitol divided into 3 or more times of consumption are needed for therapeutic effects [72].

Most of the tested products presented xylitol as the only active compound in the formulation. Regardless of this result, it is known that most commercially available products have, in their composition, other polyols or associated active compounds, to enhance the effect of this product or as a blend body agent to reduce the product cost. Besides, it can also be justified by the high cost of xylitol compared to other sugars [73]. Among the studies, products that contained xylitol as a sweetener or as a secondary compound were also 
observed, as in probiotic formulations [74]. Furthermore, other products, also related to dentistry, showed a combination of xylitol and sorbitol or fluoride to control dental biofilm, white spot lesions and improve salivary parameters [23,30,75-81]. However, there was no statistical difference between studies regarding the effect of products with isolated xylitol compared to xylitol associated with other active compounds in the present review.

The presentation form of the products varied according to the clinical outcome evaluated. Chewing gum was the most common form among studies and may have been chosen due to its greater acceptance by the general population. The more recent studies exhibited a positive effect of xylitol gums for antimicrobial activity [22,23,25,26,30,82], dental caries [30,82], dental biofilm [23,31,82], periodontal condition [23,30,31], salivary parameters [26,30,67], and gastric emptying [12]. The presentation forms less common are aerosol, tested for treat acute rhinopharyngitis in children, but without positive effect [83]; cream to treat atopic dermatitis and Staphylococcus aureus in the skin of adults [84], and milk to control S. mutans in children's biofilm and saliva $[18,85]$. It is believed that these products' presentation forms were less used among the studies because they have a more restricted applicability, as the aerosol and cream, or because they are more perishable, as the milk.

The main outcome assessed was the antimicrobial activity, in which only three studies were not in dentistry $[84,86,87]$. Regarding to oral health, the mechanism of action of xylitol is to inhibit the growth and production of acids by microorganisms present in the biofilm, such as $S$. mutans, in the glucose exposure; facilitate the remineralization of the initial dental caries and arrest the progress of dental caries; and stimulate the production of saliva to neutralize acids, providing the necessary ions for remineralization [88]. In addition, the forms of chewing gum and tablets presentation increase the salivary flow, $\mathrm{pH}$, and buffer capacity of products containing xylitol. Therefore, these products can also be indicated for patients with xerostomia, as is the case of those undergoing chemotherapy / radiotherapy [89,90].

Xylitol has also been used to regulate blood glucose levels, as this sucrose substitute has a low absorption rate in the gastrointestinal tract $[1,13,32,75]$. For the same reason, xylitol can be used for gastric emptying $[7,12,40,68,91]$.

The evaluation of these products' antimicrobial effects becomes more complicated when xylitol is associated with other compounds, resulting in major or minor positive effects. The minor effect may be due to an interaction in which one of the active compounds nullifies the other's effect. Therefore, we suggest that further studies should be carried out with isolated xylitol as well as with the chemical composition of the tested product to identify more precisely the interaction among the compounds present in these products.

Most studies showed a positive effect in relation to the evaluated outcome; however, the concentration was the only variable that showed a statistical difference. The dosage in grams per day showed a tendency for the same result, but the absence of statistical difference may have been due to the low number of studies that provided this information. The same can be applied to the other parameters, possibly because not all studies provided the necessary data for statistical analyses.

Few studies reported information related to possible side effects. Among these studies, a minority exhibited these effects (especially gastrointestinal side effects), which generally occurred mildly and in few study participants. These side effects can be justified due to low xylitol absorption in the gastrointestinal tract, which consequently results in increased bowel movement, nausea, flatulence, bloating, stomachache, diarrhea, and vomiting [13,41,92-96]. One study reported more complicated side effects (deep vein thrombosis, bronchospasm, and hemoptysis); however, the participants of this study presented a critical health condition 
since they were hospitalized with a pulmonary exacerbation of cystic fibrosis [42]. Nevertheless, the reporting of side effects is a relevant information that should be presented in future studies to alert about possible undesirable effects resulting from the use of products containing xylitol.

This bibliometric analysis presents limitations inherent to the primary studies. Several data, such as xylitol concentration, product composition, daily frequency, and intervention times, were not provided in some studies. Given these findings, further RCT with better intervention descriptions are needed to evaluate the proposed criteria. Further, the variability among the studies makes the comparison with other products problematic. Furthermore, it is impossible to conclude certainty of evidence since the methodological quality and the risk of bias of the studies were not evaluated.

However, this is the first study about the xylitol applicability and effect in different areas of health, worldwide, specifically with bibliometric approaches. In addition, the authors believe that these findings provide useful information for researchers and health professionals, especially to design new studies. Therefore, with the present results, it was possible to view that the studies about xylitol have been developed over the years and applied in different areas of health for different clinical conditions.

\section{Conclusion}

The studies with xylitol have increased worldwide, with the majority carried out with adults, in the dentistry field, and under preventive treatment. The largest number of these studies were developed in the United States and published in Caries Research. The chewing gum form is the most common, with antimicrobial activity as the main outcome. Most xylitol products presented a positive effect, and few studies reported side effects.

\section{Authors' Contributions}

\begin{tabular}{|c|c|c|}
\hline MLM & (iD) https://orcid.org/0000-0001-6777-3225 & $\begin{array}{l}\text { Conceptualization, Methodology, Formal Analysis, Investigation, Data Curation, Writing - } \\
\text { Original Draft and Writing - Review and Editing. }\end{array}$ \\
\hline KLFL & (iD) https://orcid.org/0000-0002-0113-6810 & Methodology, Formal Analysis, Investigation, Data Curation and Writing - Review and Editing. \\
\hline MBM & (iD) https://orcid.org/0000-0003-3618-190X & Formal Analysis, Investigation, Data Curation and Writing - Review and Editing. \\
\hline DM & (iD) https://orcid.org/0000-0001-7108-1117 & Methodology, Data Curation and Writing - Review and Editing. \\
\hline JMVG & (iD) https://orcid.org/0000-0003-2001-8964 & Methodology, Formal Analysis and Writing - Review and Editing. \\
\hline YWC & (iD) https://orcid.org/0000-0002-3570-9904 & Methodology, Formal Analysis and Writing - Review and Editing. \\
\hline LCM & (iD) https://orcid.org/0000-0003-1026-9401 & $\begin{array}{l}\text { Methodology, Formal Analysis, Data Curation, Writing - Review and Editing, Supervision and } \\
\text { Funding Acquisition. }\end{array}$ \\
\hline AFG & (iD) https://orcid.org/0000-0001-6467-7078 & $\begin{array}{l}\text { Conceptualization, Methodology, Formal Analysis, Investigation, Data Curation, Writing - } \\
\text { Review and Editing and Supervision. }\end{array}$ \\
\hline
\end{tabular}

\section{Financial Support}

This study was financed in part by the Coordenação de Aperfeiçoamento de Pessoal de Nível Superior - Brazil (CAPES) - Finance Code OO1, and had financial funding from the Conselho Nacional de Desenvolvimento Científico e Tecnológico (CNPq) - Process No. 401058/2016-6 - for the VantagePoint ${ }^{\mathrm{TM}}$ software.

\section{Conflict of Interest}

The authors declare no conflicts of interest.

\section{Data Availability}

The data used to support the findings of this study can be made available upon request to the corresponding author.

\section{Acknowledgments}

For cooperation in this bibliometric study, the authors would like to thank professor Adriana Cunha Correia, Anne Christin MeyerGerspach, Abrar Nahis Al-Anzi, Eda Arat Maden, Guglielmo Giuseppe Campus, Luiz Augusto da Costa Poubel, Felice Femiano, Alfonso 
Varricchio, Kemthog Mitrakul, Christiane Goeters, Pernilla Lif Holgersson, Andrea Ballini, Vinicius Silva, and Thomas Felbinger who graciously provided the full published texts for evaluation of the eligibility criteria or some information not given in the published of their previous studies.

\section{References}

[1] Natah SS, Hussien KR, Tuominen JA, Koivisto VA. Metabolic response to lactitol and xylitol in healthy men. Am J Clin Nutr 1997; 65(4):947-50. https://doi.org/10.1093/ajcn/65.4.947

[2] Alanzi A, Soderling E, Varghese A, Honkala E. Xylitol chewing gums on the market: do they prevent caries? Oral Health Prev Dent 2016; 14(5):459-66. https://doi.org/10.3290/j.ohpd.a36101

[3] Lif Holgerson P, Stecksén-Blicks C, Sjöström I, Oberg M, Twetman S. Xylitol concentration in saliva and dental plaque after use of various xylitol-containing products. Caries Res 2006; 40(5):393-7. https://doi.org/10.1159/000094284

[4] Ship JA, McCutcheon JA, Spivakovsky S, Kerr AR. Safety and effectiveness of topical dry mouth products containing olive oil, betaine, and xylitol in reducing xerostomia for polypharmacy-induced dry mouth. J Oral Rehabil 2007; 34(10):724-32. https://doi.org/10.1111/j.1365-2842.2006.01718.x

[5] Nayak PA, Nayak UA, Khandelwal V. The effect of xylitol on dental caries and oral flora. Clin Cosmet Investig Dent 2014; 6:89-94. https://doi.org/10.2147/CCIDE.S55761

[6] Riley P, Moore D, Ahmed F, Sharif MO, Worthington HV. Xylitol containing products for preventing dental caries in children and adults (Review). Cochrane Database Syst Rev 2015; 26(3):CD010743. https://doi.org/10.1002/14651858.CD010743.pub2

[7] Gong Y, Zhang Q, Qiao L, Lv D, Ruan J, Chen H, et al. Xylitol Gum Chewing to Achieve Early Postoperative Restoration of Bowel Motility After Laparoscopic Surgery. Surg Laparosc Endosc Percutan Tech 2015; 25(4):303-6. https://doi.org/10.1097/SLE.0000000000000174

[8] Lee H, Cho CW, Yoon S, Suh KS, Ryu HG. Effect of sham feeding with gum chewing on postoperative ileus after liver transplantation-a randomized controlled trial. Clin Transplant 2016; 30(11):1501-7. https://doi.org/10.1111/ctr.12849

[9] Meyer-Gerspach AC, Peterli R, Doody A, Rehfeld JF, Drewe J, Beglinger C, et al. Xylitol and erythritol induce satiation peptide release and retardation in gastric emptying in healthy humans. United European Gastroenterol J 2016; 4(5):A39-A40. https://doi.org/10.1177/2050640616663688

[10] Sezen OS, Kaytanci H, Eraslan G, Coşkuner T, Kubilay U, Aydın S, et al. Xylitol containing chewing gums in the management of chronic otitis media with effusion. Mediterranean J Otol 2008; 4:203-10.

[11] Taipale TJ, Pienihäkkinen K, Isolauri E, Jokela JT, Söderling EM. Bifidobacterium animalis subsp. lactis BB-12 in reducing the risk of infections in early childhood. Pediatr Res 2016; 79(1-1):65-9. https://doi.org/10.1038/pr.2015.174

[12] Yang P, Long WJ, Li W. Chewing xylitol gum could accelerate bowel motility recovery after elective open proctectomy for rectal cancer. Rev Invest Clin 2018; 70(1):53-8. https://doi.org/10.24875/RIC.18002428

[13] Ng AWR, Loh KK, Gupta N, Narayanana K. A polyol-stevia blended sugar replacer exhibits low glycemic response among human subjects. Clin Nutr ESPEN 2019; 33:39-41. https://doi.org/10.1016/j.clnesp.2019.07.014

[14] Wang J, Qiu J, Yi L, Hou Z, Benardot D, Cao W. Effect of sodium bicarbonate ingestion during 6 weeks of HIIT on anaerobic performance of college students. J Int Soc Sport Nutr 2019; 16(1):18.

https://doi.org/10.1186/s12970-019-0285-8

[15] Culebras-Fernandez JM, de la Hoz Riesco M, Villares Garcia C, Hurtado Fernandez-Llamazares G, Alonso Villalba A. Improvement of the nutritional condition with hypocaloric peripheral parenteral nutrition (HPPN) in the immediate postoperative period of elective abdominal surgery. Infusionsther Klin Ernahr 1987; 14(5):202-8. https://doi.org/10.1159/000222218

[16] Jauch KW, Kröner G, Hermann A, Inthorn D, Hartl W, Günther B. Postoperative infusion therapy: electrolyte solution in comparison with hypocaloric glucose and carbohydrate exchange-amino acid solutions. Zentralblatt fur chirurgie $1995 ; 120(9): 682-8$.

[17] Martínez-Pabón MC, Duque-Agudelo L, Díaz-Gil JD, Isaza-Guzmán DM, Tobón-Arroyave SI. Comparison of the effect of two sugar-substituted chewing gums on different caries- and gingivitis-related variables: a double-blind, randomized, controlled clinical trial. Clin. Oral Investig 2013; 18(2):589-98.

https://doi.org/10.1007/s00784-013-0989-0

[18] Chi DL, Zegarra G, Huerta ECV, Castillo JL, Milgrom P, Roberts MC, et al. Milk sweetened with xylitol: a proof-ofprinciple caries prevention randomized clinical trial. J Dent Child 2016; 83(3):152-60.

[19] Iftikhar PM, Ali F, Faisaluddin M, Khayyat A, De Gouvia De Sa M, Rao T. A bibliometric analysis of the top 30 most-cited articles in gestational diabetes mellitus literature (1946-2019). Cureus 2019; 11(2):e4131. https://doi.org/10.7759/cureus.4131

[20] Greenhalgh T. Searching the Literature. In: Greenhalgh T. How to Read a Paper: The Basics of Evidence-Based Medicine. 5th. ed., Chennai: Wiley, BMJ Books; 2014. pp. 17-18. 
[21] WHO. Definition of key terms. Age groups and populations. Consolidated ARV guidelines, June 2013. Available from: https://www.who.int/hiv/pub/guidelines/arv2013/intro/keyterms/en/. [Accessed on Abril 18, 2020].

[22] Aluckal E, Ankola AV. Effectiveness of xylitol and polyol chewing gum on salivary streptococcus mutans in children: A randomized controlled trial. Indian J Dent Res 2018; 29(4):445-9. https://doi.org/10.4103/ijdr.IJDR_307_16

[23] Kaur K, Nekkanti S, Madiyal M, Choudhary P. Effect of chewing gums containing probiotics and xylitol on oral health in children: A randomized controlled trial. J Int Oral Health 2018; 10(5):237-43. https://doi.org/10.4103/jioh.jioh_170_18

[24] Kayalvizhi G, Nivedha D, Sajeev R, Prathima GS, Suganya M, Ramesh V. Evaluating the efficacy of xylitol wipes on cariogenic bacteria in 19- to 35-month-old children: a double-blind randomized controlled trial. Int J Clin Pediatr Dent 2018; 11(1):13-7. https://doi.org/10.5005/jp-journals-10005-1476

[25] Oza S, Patel K, Bhosale S, Mitra R, Gupta R, Choudhary D. To determine the effect of chewing gum containing xylitol and sorbitol on mutans streptococci and lactobacilli count in saliva, plaque, and gingival health and to compare the efficacy of chewing gums. J Int Soc Prev Community Dent 2018; 8(4):354-60. https://doi.org/10.4103/jispcd.JISPCD_54_18

[26] Padminee K, Poorni S, Diana D, Duraivel D, Srinivasan MR. Effectiveness of casein phosphopeptide-amorphous calcium phosphate and xylitol chewing gums on salivary $\mathrm{pH}$, buffer capacity, and Streptococcus mutans levels: an interventional study. Indian J Dent Res 2018; 29(5):616-21. https://doi.org/10.4103/ijdr.IJDR_166_17

[27] Zajkani E, Norian O, Haghi F, Faghihzadeh S, Gholami N.. Comparison of the effect of $0.2 \%$ chlorhexidine and xylitol plus 920 ppm fluoride mouthwashes on count of salivary streptococcus mutants, a pilot study. J Dent 2018; 19(4):3014.

[28] Ballini A, Cantore S, Fotopoulou EA, Georgakopoulos IP, Athanasiou E, Bellos D, et al. Combined sea salt-based oral rinse with xylitol in orthodontic patients: clinical and microbiological study. J Biol Regul Homeost Agents 2019; 33(1):263-8.

[29] Escalante-Medina RP, Asmat-Abanto AS, Ruiz-Barrueto MA. Efecto de una pasta dental comercial conteniendo xilitol sobre el recuento de streptococcus mutans en saliva de gestantes: ensayo clínico controlado aleatorizado. Int J Odontostomatol 2019; 13(3):316-20. [In Spanish].

[30] Cagetti MG, Cocco F, Carta G, Maspero C, Campus G. Long-term efficacy of magnolia bark extract and xylitol administered through chewing gums on caries in adults: a 2-year randomized controlled intervention trial. J Funct Foods 2020; 68:103891. https://doi.org/10.1016/j.jff.2020.103891

[31] Saheer P, Parmar P, Majid S, Bashyam M, Kousalya PS, Marriette TM. Effect of sugar-free chewing gum on plaque and gingivitis among 14-15-year-old school children: a randomized controlled trial. Indian J Dent Res 2019; 30(1):616. https://doi.org/10.4103/ijdr.IJDR_247_17

[32] Wölnerhanssen BK, Cajacob L, Keller N, Doody A, Rehfeld JF, Drewe J, et al. Gut hormone secretion, gastric emptying, and glycemic responses to erythritol and xylitol in lean and obese subjects. Am J Physiol Endocrinol Metab 2016; $310(11)$ :E1053-E61. https://doi.org/10.1152/ajpendo.00037.2016.

[33] Morales-Bozo I, Rojas G, Ortega-Pinto A, Espinoza I, Soto L, Plaza A, et al. Evaluation of the efficacy of two mouthrinses formulated for the relief of xerostomia of diverse origin in adult subjects. Gerodontology 2012; 29(2):e1 103-12. https://doi.org/10.1111/j.1741-2358.2012.00626.x

[34] Gómez-Moreno G, Cabrera-Ayala M, Aguilar-Salvatierra A, Guardia J, Ramírez-Fernández MP, González-Jaranay $\mathrm{M}$, et al. Evaluation of the efficacy of a topical sialogogue spray containing malic acid $1 \%$ in elderly people with xerostomia: a double-blind, randomized clinical trial. Gerodontology 2013; 31(4):274-80. https://doi.org/10.1111/ger.12034

[35] Hashiba T, Takeuchi K, Shimazaki Y, Takeshita T, Yamashita Y. Chewing xylitol gum improves self-rated and objective indicators of oral health status under conditions interrupting regular oral hygiene. Tohoku J Exp Med 2015; 235(1):39-46. https://doi.org/10.1620/tjem.235.39

[36] Niklander S, Fuentes F, Sanchez D, Araya V, Chiappini G, Martinez R, et al. Impact of 1\% malic acid spray on the oral health-related quality of life of patients with xerostomia. J Oral Sci 2018; 60(2):278-84. https://doi.org/10.2334/josnusd.17-0164

[37] Bing AS, Mun'Im A, Rahardjo A. Efficacy of lozenges containing kepel fruit (Stelechocarpus Burahol) extract for controlling oral malodor. J App Pharm 2018; 10(1):185-9. https://doi.org/10.22159/ijap.2018.v10s1.41

[38] Aydin M, Derici MÇ, Keskek SO, Demir YI, Yeler D. Instant and freshness effect of mouth rinses on type 1 (oral) halitosis. Acta Odontol Latinoam 2019; 32(2):79-87.

[39] Soares LG, Carvalho EB, Tinoco EMB. Clinical effect of Lactobacillus on the treatment of severe periodontitis and halitosis: A double-blinded, placebo-controlled, randomized clinical trial. Am J Dent 2019; 32(1):9-13.

[40] Jakkaew B, Charoenkwan K. Effects of gum chewing on recovery of bowel function following cesarean section: a randomized controlled trial. Arch Gynecol Obstet 2013; 288:255-60. https://doi.org/10.1007/s00404-013-2727-x

[41] Taipale TJ, Pienihäkkinen K, Isolauri E, Jokela JT, Söderling EM. Bifidobacterium animalis subsp. lactis BB-12 in reducing the risk of infections in early childhood. Pediatr Res 2015; 79:65-9. https://doi.org/10.1038/pr.2015.174 
[42] Singh S, Hornick D, Fedler J, Launspach JL, Teresi ME, Santacroce TR, et al. Randomized controlled study of aerosolized hypertonic xylitol versus hypertonic saline in hospitalized patients with pulmonary exacerbation of cystic fibrosis. J Cyst Fibros 2020; 19(1):108-13. https://doi.org/10.1016/j.jcf.2019.06.016

[43] Isokangas P, Söderling E, Pienihäkkinen K, Alanen P. Occurrence of dental decay in children after maternal consumption of xylitol chewing gum, a follow-up from 0 to 5 years of age. J Dent Res 2000; 79(11):1885-9. https://doi.org/10.1177/00220345000790111201

[44] Thorild I, Lindau B, Twetman S. Effect of maternal use of chewing gums containing xylitol, chlorhexidine or fluoride on mutans streptococci colonization in the mothers' infant children. Oral Health Prev Dent 2003; 1(1):53-7.

[45] Thorild I, Lindau B, Twetman S. Salivary mutans streptococci and dental caries in three-year-old children after maternal exposure to chewing gums containing combinations of xylitol, sorbitol, chlorhexidine, and fluoride. Acta Odontol Scand 2004; 62(5):245-50. https://doi.org/10.1080/00016350410001676

[46] Bretz WA, Rosa OP, Silva SM, Corby PM, Lima OC, Milanda M, et al. On the acquisition of periodontopathic bacteria by children from mothers: a randomized double-masked placebo-controlled trial in Bauru, Brazil. Suom Hammaslaakari Lehti 2006; 13(1):18-24.

[47] Thorild I, Lindau B, Twetman S. Caries in 4-year-old children after maternal chewing of gums containing combinations of xylitol, sorbitol, chlorhexidine and fluoride. Eur Arch Paediatr Dent 2006; 7(4):241-5. https://doi.org/10.1007/BF03262559

[48] Fontana M, Catt D, Eckert GJ, Ofner S, Toro M, Gregory RL, et al. Xylitol: effects on the acquisition of cariogenic species in infants. Pediatr Dent 2009; 31(3):257-66.

[49] Nakai Y, Shinga-Ishihara C, Kaji M, Moriya K, Murakami-Yamanaka K, Takimura M. Xylitol gum and maternal transmission of mutans streptococci. J Dent Res 2010; 89(1):56-60. https://doi.org/10.1177/0022034509352958

[50] Hanno AG, Alamoudi NM, Almushayt AS, Masoud MI, Sabbagh HJ, Farsi NM. Effect of xylitol on dental caries and salivary Streptococcus mutans levels among a group of mother-child pairs. J Clin Pediatr Dent 2011; 36(2):25-30. https://doi.org/10.17796/jcpd.36.1.d4g77616714w3372

[51] Alamoudi NM, Hanno AG, Masoud MI, Sabbagh HJ, Almushayt AS, Masoud IM. Effects of xylitol on salivary mutans streptococcus, plaque level, and caries activity in a group of Saudi mother-child pairs. An 18-month clinical trial. Saudi Med J 2012a; 33(2):186-92.

[52] Alamoudi NM, Hanno AG, Sabbagh HJ, Masoud MI, Almushayt AS, El Derwi DA. Impact of maternal xylitol consumption on mutans streptococci, plaque and caries levels in children. J Clin Pediatr Dent 2012b; 37(2):163-6. https://doi.org/10.17796/jcpd.37.2.261782tq73k4414x

[53] Zhan L, Cheng J, Chang P, Ngo M, Denbesten PK, Hoover CI, et al. Effects of xylitol wipes on cariogenic bacteria and caries in young children. J Dent Res 2012; 91 (7 Suppl):85S-90S. https://doi.org/10.1177/0022034511434354

[54] Zhan L, Featherstone JD, Lo J, Krupansky C, Hoang N, DenBesten P, et al. Clinical efficacy and effects of xylitol wipes on bacterial virulence. Adv Dent Res 2012b; 24(2):117-22. https://doi.org/0.1177/0022034512449835

[55] Alamoudi NM, Hanno AG, Almushayt AS, Masoud MI, El Ashiry EA, El Derwi DA. Early prevention of childhood caries with maternal xylitol consumption. Saudi Med J 2014; 35(6):592-7.

[56] Fejerskov O. Changing paradigms in concepts on dental caries: consequences for oral health care. Caries Res 2004; 38(3):182-91. https://doi.org/10.1159/000077753

[57] Simón-Soro A, Mira A. Solving the etiology of dental caries. Trends Microbiol 2015; 23(2):76-82. https://doi.org/10.1016/j.tim.2014.10.010

[58] Ur-Rehman S, Mushtaq Z, Zahoor T, Jamil A, Murtaza MA. Xylitol: a review on bioproduction, application, health benefits, and related safety issues. Crit Rev Food Sci Nutr 2015; 55(11):1514-28. https://doi.org/10.1080/10408398.2012.702288

[59] Normando D. The Brazilian dental science. Dental Press J Orthod 2014; 19:14. https://doi.org/10.1590/2176-9451.19.2.014-014.edt

[60] Arshad AI, Ahmad P, Dummer PMH, Alam MK, Asif JA, Mahmood Z, et al. Citation classics on dental caries: a systematic review. Eur J Dent 2020; 14(1):128-43. https://doi.org/10.1055/s-0040-1703419

[61] Ainamo J, Asikainen S, Ainamo A, Lahtinen A, Sjöblom M. Plaque growth while chewing sorbitol and xylitol simultaneously with sucrose flavored gum. J Clin Periodontol 1979; 6(6):397-406. https://doi.org/10.1111/j.1600-051x.1979.tbo1938.x

[62] Lingström P, Lundgren F, Birkhed D, Takazoe I, Frostell G. Effects of frequent mouthrinses with palatinose and xylitol on dental plaque. Eur J Oral Sci 1997; 105(2):162-9. https://doi.org/10.1111/j.1600-0722.1997.tbo0195.x

[63] Rodgers A, Bungane N, Allie-Hamdulay S, Lewandowski S, Webber D. Calciuria, oxaluria and phosphaturia after ingestion of glucose, xylitol and sorbitol in two population groups with different stone-risk profiles. Urol Res 2009; 37(3):121-5. https://doi.org/10.1007/s00240-009-0184-6

[64] Rösing CK, Gomes SC, Bassani DG, Oppermann RV. Effect of chewing gums on the production of volatile sulfur compounds (VSC) in vivo. Acta Odontol Latinoam 2009; 22(1):11-4.

[65] Ribelles Llop M, Guinot Jimeno F, Mayné Acién R, Bellet Dalmau LJ. Effects of xylitol chewing gum on salivary flow rate, $\mathrm{pH}$, buffering capacity and presence of Streptococcus mutans in saliva. Eur J Paediatr Dent 2012; 11(1):9-14. 
[66] Montanuci LMGM, Volpato LER, França DCC, Aguiar SMHCA, Machado MAAM. Efeito de diferentes gomas de mascar sobre o pH salivar de crianças. Pesqui Bras Odontopediatria Clín Integr 2013; 13(1):23-9. https://doi.org/10.4034/PBOCI.2013.131.04 [In Portuguese].

[67] Manisha, Gurunathan D, Senthil Kumar M. Comparison of the effect of salt water rinse, sugar-free chewing gum and tooth brushing on the $\mathrm{pH}$ of saliva. International $\mathrm{J}$ Res Pharm Pract 2019; 10(2):922-6. https://doi.org/10.26452/ijrps.v10i2.276

[68] Shafer RB, Levine AS, Marlette JM, Morley JE. Effects of xylitol on gastric emptying and food intake. Am J Clin Nutr 1987; 45(4):744-7. https://doi.org/10.1093/ajcn/45.4.744

[69] Olsson H, Spak CJ, Axell T. The effect of a chewing gum on salivary secretion, oral mucosal friction, and the feeling of dry mouth in xerostomic patients. Acta Odontol Scand 1991; 49(5):273-9. https://doi.org/10.3109/00016359109005919

[70] Söderling E, ElSalhy M, Honkala E, Fontana M, Flannagan S, Eckert G, et al. Effects of short-term xylitol gum chewing on the oral microbiome. Clin. Oral Investig 2015; 19(2):237-44. https://doi.org/10.1007/s00784-014-1229-y

[71] Kim DH, Kim Y, Lim IG, Cho JH, Park YJ, Kim SW, et al. Effect of postoperative xylitol nasal irrigation on patients with sinonasal diseases. Otolaryngol Head Neck Surg 2018; 160:550-5. https://doi.org/10.1177/0194599818802815

[72] Ly KA, Milgrom P, Rothen M. The potential of dental-protective chewing gum in oral health interventions. J Am Dent Assoc 2008; 139(3):553-63. https://doi.org/10.14219/jada.archive.2008.0215

[73] Mäkinen KK, Olak J, Russak S, Saag M, Seedre T, Vasar R, et al. Polyol-combinant saliva stimulants: a 4-month pilot study in young adults. Acta Odontol Scand 1998; 56(2):90-4. https://doi.org/10.1080/00016359850136049

[74] Çaglar E, Kavaloglu SC, Kuscu OO, Sandalli N, Holgerson PL, Twetman S. Effect of chewing gums containing xylitol or probiotic bacteria on salivary mutans streptococci and lactobacilli. Clin Oral Investig 2007; 11(4):425-9. https://doi.org/10.1007/s00784-007-0129-9

[75] Iwata C, Nakagaki H, Morita I, Sekiya T, Goshima M, Abe T, et al. Daily use of dentifrice with and without xylitol and fluoride: effect on glucose retention in humans in vivo. Arch Oral Biol 2003; 48(5):389-95. https://doi.org/10.1016/s0003-9969(03)00033-5

[76] Pretty IA, Edgar WM, Higham SM. A study to assess the efficacy of a new detergent free, whitening dentifrice in vivo using QLF planimetric analysis. Br Dent J 2004; 197(9):561-6. https://doi.org/10.1038/sj.bdj.4811809

[77] Mata AD, da Silva Marques DN, Silveira JM, Marques JR, de Melo Campos Felino ET, Guilherme NF. Effects of gustatory stimulants of salivary secretion on salivary $\mathrm{pH}$ and flow: a randomized controlled trial. Oral Dis 2009; 15(3):220-8. https://doi.org/10.1111/j.1601-0825.2009.01513.x

[78] Marques DNS, da Mata AD, Patto JM, Barcelos FA, de Almeida Rato Amaral JP, de Oliveira MC, et al. Effects of gustatory stimulants of salivary secretion on salivary $\mathrm{pH}$ and flow in patients with Sjogren's syndrome: a randomized controlled trial. J Oral Pathol Med 2011; 40(10):785-92. https://doi.org/10.1016/j.rpemd.2013.12.135

[79] Tao DY, Shu CB, Lo EC, Lu HX, Feng XP. A randomized trial on the inhibitory effect of chewing gum containing tea polyphenol on caries. J Clin Pediatr Dent 2013; 38(1):67-70. https://doi.org/10.17796/jcpd.38.1.c0tm02w572488064

[80] Cruz M, Marques D, Trindade R, Lopes M, Pereira R, Mata A. Effects of gustatory stimulants of salivary secretion and its fluoride release in saliva. Rev Port Estomatol Cir Maxilofac 2014; 55(1):29-35. https://doi.org/10.1016/j.rpemd.2013.12.135

[81] Güçlü ZA, Alaçam A, Coleman NJ. A 12-Week Assessment of the treatment of white spot lesions with CPP-ACP paste and/or fluoride varnish. Biomed Res Int 2016; 2:8357621. https://doi.org/10.1155/2016/835762 1

[82] Cocco F, Carta G, Cagetti MG, Strohmenger L, Lingström P, Campus G. The caries preventive effect of 1-year use of low-dose xylitol chewing gum. A randomized placebo-controlled clinical trial in high-caries-risk adults. Clin Oral Investig 2017; 21(9):2733-40. https://doi.org/10.1007/s00784-017-2075-5

[83] Varricchio A, Capasso M, Avvisati F, Varricchio AM, De Lucia A, Brunese FP, et al. Inhaled hyaluronic acid as ancillary treatment in children with bacterial acute rhinopharyngitis. J Biol Regul Homeost Agents 2014; 28(3):53743.

[84] Katsuyama M, Kobayashi Y, Ichikawa H, Mizuno A, Miyachi Y, Matsunaga K, et al. A novel method to control the balance of skin microflora: Part 2. A study to assess the effect of a cream containing farnesol and xylitol on atopic dry skin. J Dermatol Sci 2005; 38(3):207-13. https://doi.org/10.1016/j.jdermsci.2005.01.003

[85] Pahumunto N, Piwat S, Chanvitan S, Ongwande W, Uraipana S, Teanpaisan R. Fermented milk containing a potential probiotic Lactobacillus rhamnosus SD11 with maltitol reduces Streptococcus mutans: a double-blind, randomized, controlled study. J Dent Sci 2020; 15(4):403-410. https://doi.org/10.1016/j.jds.2020.03.003

[86] Uhari M, Kontiokari T, Koskela M, Niemelä M. Xylitol chewing gum in prevention of acute otitis media: double blind randomised trial. BMJ 1996; 313 (7066):1180-4. https://doi.org/10.1136/bmj.313.7066.1180

[87] Zabner J, Seiler MP, Launspach JL, Karp PH, Kearney WR, Look DC, et al. The osmolyte xylitol reduces the salt concentration of airway surface liquid and may enhance bacterial killing. Proc Natl Acad Sci USA 2000; 97(21):1 16149. https://doi.org/10.1073/pnas.97.21.11614 
[88] Ly KA, Milgrom P, Roberts MC, Yamaguchi DK, Rothen M, Mueller G. Linear response of mutans streptococci to increasing frequency of xylitol chewing gum use: a randomized controlled trial. BMC Oral Health 2006; 24(6):6. https://doi.org/10.1186/1472-6831-6-6.J.G

[89] Pinna R, Campus G, Cumbo E, Mura I, Milia E.. Xerostomia induced by radiotherapy: an overview of the physiopathology, clinical evidence, and management of the oral damage. Ther Clin Risk Manag 2015; 11:171-88. https://doi.org/10.2147/TCRM.S70652

[90] Martín M, Marín A, López M, Liñán O, Alvarenga F, Büchser , et al. Products based on olive oil, betaine, and xylitol in the post-radiotherapy xerostomia. Rep Pract Oncol Radiother 2017; 22(1):71-6. https://doi.org/10.1016/j.rpor.2016.09.008

[91] Apostolopoulos P, Kalantzis C, Gralnek IM, Liatsos C, Tsironis C, Kalantzis N. Clinical trial: Effectiveness of chewing-gum in accelerating capsule endoscopy transit time - A prospective randomized, controlled pilot study. Aliment Pharmacol Ther 2008; 28(4):405-11. https://doi.org/10.1111/j.1365-2036.2008.03762.x

[92] Lenkkeri AM, Pienihakkinen K, Hurme S, Alanen P. The caries-preventive effect of xylitol/maltitol and erythritol/maltitol lozenges: results of a double-blinded, cluster-randomized clinical trial in an area of natural fluoridation. Int J Paediatr Dent 2012; 22(3):180-90. https://doi.org/10.1111/j.1365-263X.2011.01182.x

[93] Seki M, Karakama F, Kawato T, Tanaka H, Saeki Y, Yamashita Y. Effect of xylitol gum on the level of oral mutans streptococci of preschoolers: block-randomised trial. Int Dent J 2011;61(5):274-80.

https://doi.org/10.1111/j.1875-595X.2011.00073.x

[94] Taipale T, Pienihakkinen K, Salminen S, Jokela J, Söderling E. Bifidobacterium animalis subsp. lactis BB-12 administration in early childhood: a randomized clinical trial of effects on oral colonization by mutans streptococci and the probiotic. Caries Res 2012; 46(1):69-77. https://doi.org/10.1159/000335567

[95] Bader JD, Vollmer WM, Shugars DA, Gilbert GH, Amaechi BT, Brown JP, et al. Results from the Xylitol for Adult Caries Trial (X-ACT). J Am Dent Assoc 2013; 144(1):2 1-30. https://doi.org/10.14219/jada.archive.2013.0010

[96] Vernacchio L, Corwin MJ, Vezina RM, Pelton SI, Feldman HA, Coyne-Beasley T, et al. Xylitol Syrup for the Prevention of Acute Otitis Media. Pediatrics 2014; 133(2):289-95. https://doi.org/10.1542/peds.2013-2373 